\title{
FAKTOR PENENTU PENGUNGKAPAN INFORMASI LAPORAN KEUANGAN MELALUI LAMAN INTERNET: STUDI EMPIRIS PADA PERUSAHAAN YANG TERDAFTAR DI BURSA EFEK INDONESIA
}

\author{
Gatot Soepriyanto $^{1}$; Dustinova ${ }^{2}$ \\ ${ }^{1}$ Jurusan Akuntansi, Fakultas Ekonomi dan Komunikasi, BINUS University \\ ${ }^{2}$ Ernst \& Young Indonesia \\ Jln. K.H. Syahdan No. 9, Palmerah, Jakarta Barat 11480 \\ gsoepriyanto@binus.edu
}

\begin{abstract}
The study aims to investigate the factors affecting companies to disclose financial statement information through internet (internet financial reporting). Assessment of the disclosure uses 29 criteria as used by Abdelsalam et al (2007). The method of testing hypotheses in this study is the linear regression method by comparing the extensive disclosure of financial statements on the internet as the dependent variable and type of industry, firm size, profitability, leverage levels and types of auditors as independent variables. Through the observation 69 listed companies in the KOMPAS100 directory, the study concluded that 59.17\% of companies meet the criteria for such disclosure made by Abdelsalam et al (2007). Consistent with some previous studies, factors that play an important role on the level of disclosure is the company's size and corporate profitabilty.
\end{abstract}

Keywords: internet financial report, extent of disclosure, company's size, profitability

\begin{abstract}
ABSTRAK
Penelitian ini bertujuan untuk menginvestigasi faktor-faktor yang mempengaruhi perusahaan dalam mengungkapan informasi laporan keuangan melalui laman internet (internet financial reporting). Penilaian luas pengungkapan menggunakan 29 kriteria seperti yang digunakan oleh Abdelsalam et al (2007). Metoda pengujian hipotesis dipenelitian ini adalah metoda regresi linier dengan membandingkan luas pengungkapan laporan keuangan diinternet sebagai variabel dependen dan jenis industry, ukuran perusahaan, tingkat keuntungan, tingkat pengungkit serta jenis auditor sebagai variabel independen. Melalui observasi pada 69 laman perusahaan yang terdaftar di KOMPAS 100, penelitian ini menyimpulkan bahwa 59, 17\% perusahaan memenuhi kriteria pengungkapan seperti yang dilakukan oleh Abdelsalam et al (2007). Konsisten dengan beberapa penelitian sebelumnya, faktor yang berperan penting terhadap tingkat pengungkapan adalah ukuran perusahaan dan tingkat keuntungan perusahaan.
\end{abstract}

Kata kunci: laporan keuangan internet, luas pengungkapan, ukuran perusahaan, tingkat keuntungan 


\section{PENDAHULUAN}

Penyampaian informasi laporan keuangan dengan media internet dikenal dengan IFR (Internet Financial Report) atau laporan keuangan berbasis internet. Cukup banyak penelitian yang menjadikan laporan keuangan berbasis internet sebagai objek penelitian. Pada umumnya, penelitian-penelitian ini berusaha menganalisa dan mengevaluasi informasi seperti apa yang diungkapkan perusahaan dalam laman (website) perusahaannya (corporate website) di internet. Selain itu, terdapat pula penelitian yang berusaha mempelajari penggunaan teknologi internet dan presentasi laman perusahaan untuk menyajikan laporan keuangan berbasis internet. Karena tidak ada aturan yang jelas mengatur pengungkapan informasi keuangan pada laman perusahaan, banyak peneliti yang mengembangkan sendiri kriteria untuk mengukur keefektifan laporan keuangan berbasis internet.

Sebagai contoh, Sriram dan Laksmana (2006) menggunakan gabungan antara rekomendasi Komite Jenkins (1994) dan penelitian Meek, G.K., Roberts, C.B., dan Gray, S.J. (1995). Xiao, Yang, dan Chow (2004) mengabungkan antara kriteria yang diwajibkan oleh CSRC (China Securities Regulatory Commison) dengan kriteria-kriteria tambahan. Abdelsalam, Bryant, dan Street (2007) menggunakan gabungan literatur akademik antara lain Loranger dan Nielsen (2003), Nielsen (1999) serta literatur mengenai bagaimana berhubungan dengan investor. Adapula peneliti yang juga mengarahkan penelitiannya pada penggunaan teknologi internet dan bagaimana perusahaan menyajikan laporan keuangan berbasis internet seperti penggunaan multimedia, format laman, dokumentasi video dan sebagainya. Penelitian tersebut diantaranya adalah Asbough, Johnstone, dan Warfield (1999), Xiao et al (2004), dan Budisusetyo dan Almilia (2008). Variabel-variabel yang digunakan untuk menilai tingkat keluasan laporan keuangan berbasis internet pada umumnya adalah variabel seperti besar perusahaan, jenis industri, tingkat keuntungan, saham, direktur yang ditugaskan, dan penggunaan auditor eksternal.

Semakin pesatnya perkembangan teknologi informasi terutama internet, menjadikan laporan keuangan berbasis internet penting untuk dipelajari lebih lanjut. Terutama dalam hal penyusunan standar aturan yang baik sehingga terdapat keseragaman informasi pada laman perusahaan dan informasi tersebut bernilai guna bagi para pengguna informasi laporan keuangan berbasis internet. Pentingnya topik ini terbukti dari penelitian-penelitian yang terus dilakukan di berbagai negara, seperti beberapa contoh yang disebutkan pada paragraf sebelumnya. Jika teknologi internet digunakan dengan baik sebagai salah satu media penyampaian laporan keuangan, maka informasi keuangan berbasis internet akan mampu mengurangi asimetri informasi (information assymetry) ke masyarakat luas tanpa ada batasan ruang dan waktu. Namun tentunya informasi ini harus dilindungi dengan aturan yang kuat, agar tidak ada pihak yang dirugikan karena informasi yang tidak benar.

Indonesia sebagai negara yang berkembang dengan 300 lebih perusahaan yang tercatat sahamnya di Bursa Efek Indonesia, sudah seharusnya menaruh perhatian pada perkembangan laporan keuangan berbasis internet. Namun sampai dengan saat ini, belum ada standar yang mengatur praktik laporan keuangan berbasis internet di Indonesia. Selain itu, tidak banyak penelitian yang meneliti praktik laporan keuangan berbasis internet. Di Indonesia, salah satu penelitian yang meneliti topik ini adalah penelitian yang dilakukan oleh Budisusetyo dan Almilia (2008). Penelitian Budisusetyo dan Almilia (2008) bertujuan untuk mengukur kualitas dari laporan keuangan berbasis internet sektor perbankan dan sektor manufaktur pada Bursa Efek Jakarta, sekarang Bursa Efek Indonesia. Kriteria penelitian ini terbagi empat bagian yaitu konten, waktu, teknologi, dan bantuan pengguna. Keterbatasan penelitian ini adalah hanya meneliti perusahaan pada 19 sektor perbankan. Selain itu, penelitian ini tidak meneliti informasi-informasi keuangan apa saja yang diungkapkan perusahaan pada laman perusahaan sebagai praktik laporan keuangan berbasis internet. 
Berdasarkan latar belakang yang ada, penelitian ini mengambil fokus pada laporan keuangan berbasis internet untuk meneliti lebih jauh mengenai praktik laporan keuangan berbasis internet di Indonesia. Kondisi yang menjadikan penelitian ini berbeda dengan penelitian sejenis di Indonesia adalah penelitian ini akan menitik beratkan pada faktor-faktor yang menentukan luas pengungkapan informasi keuangan dalam laman perusahaan. Untuk menilai sejauh mana perusahaan mangungkapkan informasi keuangan pada lamannya, penelitian ini akan menggabungkan beberapa kriteria dari penelitian-penelitian sebelumnya. Adapun variabel yang akan digunakan adalah jenis industri, besar perusahaan, tingkat keuntungan perusahaan, tingkat pengungkit, dan kelompok auditor. Objek penelitian ini adalah 100 perusahaan teratas yang terdaftar dalam Bursa Efek Indonesia berdasarkan indeks yang dikeluarkan Bursa Efek Indonesia dengan KOMPAS.

\section{Tinjauan Pustaka dan Pengembangan Hipotesis}

Penelitian mengenai pelaporan keuangan berbasis internet, telah banyak dilakukan. Pada umumnya, penelitian-penelitian ini memiliki kriteria pengukuran yang serupa untuk menilai tingkat pengungkapan informasi keuangan pada laman sebuah perusahaan. Intinya, kriteria pengukuran ini terbagi dua yaitu bagaimana cara informasi disajikan dalam laman perusahaan dan informasi apa saja yang diungkapkan dalam laman perusahaan.

Penelitian Asbough et al (1999) memiliki tiga kondisi untuk menilai kelengkapan informasi yang diungkapkan dalam laman perusahaan yaitu: laporan keuangan, penghubung informasi keuangan di luar laman perusahaan, dan penghubung ke laman SEC (Security and Exchange Comission's). Penelitian ini juga menilai rentang waktu informasi, kemudahaan akses informasi, dan kegunaan informasi yang disajikan.

Keunggulan penelitian ini adalah peneliti berkomunikasi dengan perusahaan lewat laman perusahaan yang diteliti. Dalam hal ini, peneliti bertindak seolah-olah sebagai pengguna laman lalu memberikan umpan balik kepada perusahaan. Selain itu, peneliti juga menilai kebiasaan pengguna informasi dalam menggunakan laman perusahaan dengan memantau bagian apa saja yang sering dikunjungi pada laman suatu perusahaan.

Penelitian sejenis di Indonesia adalah Budisusetyo dan Almilia (2008) yang mengambil objek penelitian mengenai laporan keuangan berbasis internet di Indonesia. Penelitian ini menitik beratkan pada teknologi internet dan presentasi informasi laporan keuangan pada laman perusahaan. Hal ini dapat terlihat dari tujuan dalam penelitian yaitu untuk mengukur kualitas laporan keuangan berbasis internet industri manufaktur dan bank yang terdaftar pada Bursa Efek Jakarta (sekarang Bursa Efek Indonesia). Pengembangan kriteria pengukuran didasarkan pada penelitian Lymer et al (1999). Isi dari kriteria ini terbagi menjadi empat bagian yaitu konten, waktu, teknologi, dan bantuan pengguna.

Dalam simpulannya, penelitian ini menyebutkan bahwa terdapat perbedaan pengungkapan informasi keuangan dari 19 Bank yang diteliti. Perbedaan ini berdasarkan pada kebutuhan dan tujuan masing-masing Bank. Tidak semua bank menggunakan teknologi internet secara maksimal. Terakhir, penelitian ini menyarankan agar disusunnya suatu acuan sebagai standar yang dapat diikuti oleh perusahaan khususnya bank dalam hal pengungkapan informasi laporan keuangan lewat internet.

Adapun keterbatasan penelitian ini adalah sampel yang digunakan hanya mencakup 19 bank yang terdaftar di Bursa Efek Indonesia sehingga hasil penelitian tidak bisa digeneralisir pada sektor-sektor usaha yang lain. 


\section{Pengembangan Hipotesis}

\section{Pengaruh Jenis Industri dengan Praktik Laporan Keuangan Berbasis Internet}

Perusahan yang sudah terdaftar dalam suatu bursa efek, tentunya terdiri dari berbagai jenis industri seperti industri pertanian, industri pertembangan, industri kimia, industri barang konsumsi, dan sebagainya. Tiap-tiap industri ini tentunya memiliki kepentingan masing-masing dalam penyampaian informasi. Sehingga sangat mungkin adanya perbedaan hal-hal yang diungkapkan oleh perusahaan dari industri yang berbeda. Selain kepentingan yang berbeda, tentunya sasaran penyampaian informasi juga berbeda serta aturan yang digunakan juga berbeda.

Kondisi yang sama juga akan ditemukan dalam pengungkapan laporan keuangan berbasis internet. Penelitian-penelitian terdahulu yang mendukung pernyataan ini adalah penelitian Marston (2003), Xiao et al (2004), dan Abdelsalam (2007). Pada ketiga penelitian ini, industri dibagi menjadi dua kelompok yaitu industri berteknologi tinggi dan industri nonteknologi tinggi. Pembagian dua kelompok industri ini didasarkan pada pemikiran bahwa industri dengan teknologi tinggi akan cenderung memiliki motivasi lebih tinggi dalam kegiatan laporan keuangan berbasis internet. Selain itu, industri dengan teknologi tinggi diperkirakan akan melakukan banyak pengungkapan berkenaan dengan teknologi yang digunakan.

Dengan penjelasan-penjelasan di atas, maka jenis industri akan dijadikan sebagai salah satu variabel penelitian dalam penelitian ini. Jenis industri akan diujicobakan untuk melihat tingkat pengungkapan laporan keuangan perusahaan yang terdaftar di Bursa Efek Indonesia yang menjadi sampel penelitian. Maka dari itu dapat dinyatakan hipotesis pertama dalam bentuk hipotesis alternatif sebagai berikut:

$H A_{1}$ : Jenis industri berpengaruh terhadapat informasi laporan keuangan yang diungkapkan pada laman perusahaan.

\section{Pengaruh Ukuran Perusahaan dengan Praktik Laporan Keuangan Berbasis Internet}

Terdapat beberapa penelitian mengenai IFR sebelumnya yang menjadikan ukuran perusahaan sebagai salah satu variabel penelitian yang turut menentukan luasnya pengungkapan laporan keuangan berbasis internet. Di antaranya adalah Sriram dan Laksmana (2006), Asbough et al (1999), Marston (2003), serta Allam dan Lymer (2003). Kemungkinan adanya tingkat keluasan pengungkapan laporan keuangan berbasis internet yang berbeda bila ditinjau dari ukuran perusahaan adalah kompleksitas yang dimiliki perusahaan yang cenderung meningkat seiring semakin besarnya ukuran suatu perusahaan. Beberapa kompleksitas yang dimaksud seperti target usaha yang semakin tinggi sehingga membutuhkan kinerja yang lebih baik, persaingan usaha yang semakin ketat sehingga perusahaan membutuhkan strategi bersaing yang lebih unggul, hubungan dengan pemerintah serta pihak regulator terkait, dan sebagainya. Kompleksitas seperti ini yang pada akhirnya akan mendorong perusahaan untuk mengungkapkan informasi laporan keuangan yang lebih luas pada lamannya di internet.

Sriram dan Laksmana (2006) menyebutkan salah satu pengaruh keluasan laporan keuangan yang berbeda seiring ukuran perusahaan yang semakin besar adalah adanya indikasi mengenai agency theory. Perusahaan besar tentu memiliki target usaha yang tinggi sesuai keinginan para pemilik (pemegang saham). Di saat yang bersamaan, pihak managemen harus berusaha untuk memenuhi target tersebut. Tidak menutup kemungkinan adanya ketidaksesuaian antara keinginan pemilik dengan performa managemen. Managemen bisa saja memberikan informasi yang tidak sesuai dengan kenyataan hanya untuk memenuhi target yang diinginkan oleh pemilik. Sehingga untuk mengurangi kondisi agency theory ini, perusahaan harus mengeluarkan biaya yang disebut agency cost. Menurut Sriram dan Laksmana (2006), agency cost dapat dikurangi dengan adanya pengungkapan informasi 
laporan keuangan pada laman perusahaan. Pendapat ini juga sejalan dengan penelitian Marston (2003) yang mengatakan bahwa dengan tingkat keluasan informasi laporan keuangan yang lebih, perusahaan dapat mengurangi agency cost. Mekanisme berkurangnya agency cost menurut Marston (2003) adalah dengan adanya informasi lebih yang diungkapkan dalam laporan keuangan berbasis internet, masyarakat umum juga dapat memantau kinerja managemen. Sehingga perusahaan tidak perlu mengeluarkan biaya tambahan untuk menjamin informasi yang dilaporkan managemen tidak bersifat menyesatkan.

Berhubungan dengan persaingan dengan kompetitor lain, internet dapat menjadi media yang baik bagi perusahaan untuk memberi informasi yang dapat memotivasi para stakeholder untuk bertindak sesuai harapan perusahaan. Sehingga dalam hal komunikasi dan promosi, perusahaan dapat selangkah lebih maju dari para pesaingnya. Kondisi ini erat kaitanya dengan signalling theory, di mana perusahaan memberikan informasi sebagai suatu tanda bahwa perusahaan menginginkan pihak yang menerima informasi bertindak searah dengan keinginan perusahaan. Hal ini sejalan dengan penelitian Marston (2003) dan Asbough et al (1999) yang menyatakan bahwa perusahaan besar cenderung memberikan informasi laporan keuangan secara lebih luas dalam lamannya kepada masayarakat sesuai dengan kebutuhan perusahaan. Sehingga dari informasi tersebut perusahaan secara tidak langsung dapat menggerakan pihak yang menerima informasi untuk melakukan apa yang diinginkan oleh perusahaan.

Berdasarkan penjelasan di atas, ukuran perusahaan diperkirakan akan memberikan kontribusi terhadap tingkat keluasan laporan keuangan berbasis internet. Ukuran perusahaan akan diujicobakan dalam menentukan luasnya informasi laporan keuangan yang dilaporkan perusahaan yang terdaftar di Bursa Efek Indonesia pada laman masing-masing perusahaan. Maka dari itu dapat dinyatakan suatu hipotesis dalam bentuk hipotesis alternatif sebagai berikut:

$H A_{2}$ : Ukuran perusahaan berpengaruh terhadap informasi laporan keuangan yang diungkapkan pada laman perusahaan.

\section{Pengaruh Tingkat Keuntungan Perusahaan dengan Praktik Laporan Keuangan Berbasis Internet}

Keuntungan merupakan salah satu unsur yang menarik untuk dianalisa dari laporan keuangan. Para investor dan para pemegang saham tentunya memiliki perhatian yang lebih terhadap laporan perusahaan atas keuntungan. Terutama jika keuntungan perusahaan tersebut sebagain besar dialokasikan untuk pembagian deviden. Jika pembagian deviden sejalan dengan semakin meningkatnya keuntungan, maka akan banyak investor baru yang berusaha menanamkan modalnya pada perusahaan dan para pemegang saham akan termotivasi untuk tetap menjaga kepemilikan sahamnya pada perusahaan.

Penjelasan di atas sejalan dengan pembentukan salah satu hipotesis dalam penelitian Marston (2003). Marston (2003) menggunakan tingkat keuntungan sebagai salah satu variabel penelitiannya dengan alasan tingkat keuntungan tinggi sangat berpengaruh terhadap saham yang beredar di masyarakat sehingga dibutuhkan suatu informasi yang lebih yang harus di sampaikan. Alasan kedua adalah perusahaan dengan keuntungan tinggi memiliki banyak informasi yang seharusnya diungkapkan kepada masyarakat. Informasi yang dimaksud tentunya adalah informasi yang berhubungan dengan sumber-sumber keuntungan perusahaan.

Adapun penelitian lain yang juga menggunakan tingkat keuntungan sebagai salah satu variabelnya adalah penelitian Asbough et al (1999), Pervan (2004), Sriram dan Laksmana (2006), dan Abdelsalam et al (2007). Umumnya tingkat keuntungan pada penelitian-penelitian tersebut diambil berdasarkan rasio ROA (Return on Asset) atau tingkat pengembalian aset terhadap laba. 
Sejalan dengan penjelasan di atas, penelitian ini juga akan menggunakan tingkat keuntungan sebagai salah satu variabel dalam penelitian. Tingkat keuntungan ini nantinya akan digunakan untuk menguji luasnya informasi laporan keuangan yang diungkapkan perusahaan yang terdaftar di Bursa Efek Indonesia. Dengan demikian pernyataan untuk hipotesis ketiga dalam bentuk hipotesis alternatif adalah sebagai berikut:

$H A_{3}$ : Tingkat keuntungan perusahaan berpengaruh terhadap informasi laporan keuangan yang diungkapkan pada laman perusahaan.

\section{Pengaruh Tingkat Pengungkit dengan Praktik Laporan Keuangan Berbasis Internet}

Dalam menjalankan usaha, perusahaan memerlukan modal baik modal berupa kas maupun modal berbentuk pinjaman. Pada umumnya, modal perusahaan merupakan kombinasi antara modal kas dengan modal yang berasal dari utang. Penggunaan modal yang bersumber dari utang akan memicu pengawasan dan pemantauan dari para debitor maupun pemegang saham. Akan muncul kekhawatiran debitor atau pemegang saham atas posisi neraca tiap tahun perusahaan, terutama perusahaan dengan tingkat pengungkit (leverage) yang besar. Pertanyaan yang akan selalu muncul adalah bagaimana tingkat solvabilitas dan likuiditas perusahaan dengan tingkat pengungkit tertentu. Kemudian, debitor akan berfikir apakah perusahaan mampu melunasi utang yang dipinjam. Sedang bagi pemegang saham, apakah investasi yang ditanam dapat bertahan dengan aman atau tidak. Maka dari itu, luas pengungkapan informasi laporan keuangan berbasis internet ditinjau dari tingkat pengungkit perlu diujicoba lebih lanjut.

Xiao et al (2004) menggunakan tingkat pengungkit sebagai salah satu variabel penelitiannya dalam meneliti laporan keuangan berbasis internet. Penelitian Xiao et al (2004) menyatakan apabila tingkat pengungkit suatu perusahaan semakin tinggi, maka para debitor dan pemegang saham akan termotivasi untuk meminta informasi lebih tentang kesehatan dan keberlangsungan perusahaan.

Berdasar pernyataan Xiao et al (2004) tersebut, tingkat pengungkit juga akan diujicobakan pada pengungkapan laporan keuangan berbasis internet perusahaan yang terdaftar pada Bursa Efek Indonesia. Karena diperkirakan tingkat pengungkit juga akan memberikan dampak pada luasnya pengungkapan informasi laporan keuangan pada laman perusahaan. Maka dari itu dapat dinyatakan hipotesis alternatif keempat sebagai berikut:

$H A_{4}$ : Tingkat pengungkit berpengaruh terhadap informasi laporan keuangan yang diungkapkan pada laman perusahaan.

\section{Pengaruh Jenis Auditor dengan Praktik Laporan Keuangan Berbasis Internet}

Sudah menjadi salah satu persyaratan bahwa perusahaan yang terdaftar sahamnya di Bursa Efek, harus menggunakan jasa auditor untuk menilai laporan keungannya apakah telah disajikan secara wajar dan dapat diandalkan. Banyak Kantor Akuntan Publik yang menawarkan jasa audit dan dapat memberikan opini audit atas suatu laporan keuangan. Namun kualitas opini yang dihasilkan oleh tiap Kantor Akuntan Publik tidaklah sama. Kantor Akuntan Publik besar terutama yang termasuk dalam big-4 (Pricehousewatercooper, Ernst\&Young, Deloitte, dan KPMG, untuk di Indonesia) tentu memiliki kualitas opini audit yang lebih dapat diandalkan sesuai dengan reputasi keempat KAP tersebut. Semakin baik reputasi suatu KAP tentu opini yang dikeluarkan semakin dipercaya dan dapat diandalkan. Sehubungan dengan pengungkapan laporan keuangan berbasis internet, reputasi KAP dapat turut menjamin bahwa informasi yang diungkapkan perusahaan berkaitan dengan laporan keuangan pada lamannya. Dengan demikian, diperkirakan bahwa dengan penggunaan KAP tertentu, perusahaan dapat memberikan informasi yang lebih luas mengenai laporan keuangan berbasis internet. 
Penjelasan di atas sejalan dengan penelitian Xiao et al (2004) yang menyatakan bahwa reputasi KAP besar dapat menjamin kebenaran informasi yang disampaikan perusahaan berkenaan dengan laporan keuangan berbasis internet. Selain itu pada penelitian Xiao et al (2004) juga dijelaskan bahwa KAP besar bisa saja memberikan suatu standar yang dapat digunakan oleh perusahaan dalam hal pengungkapan laporan keuangan berbasis internet.

Variabel jenis auditor ini akan diujicobakan untuk perusahaan yang terdafatar di Bursa Efek Indonesia. Jenis auditor akan menjadi salah satu variabel yang menentukan luas pengungkapan laporan keuangan berbasis internet dalam penelitian ini. Selanjutnya dapat di bentuk hipotesis alternatif kelima sebagai berikut:

$H A_{5}$ : Jenis auditor (big-4 atau non big-4) berpengaruh terhadap informasi laporan keuangan yang diungkapkan pada laman perusahaan.

\section{METODE}

\section{Variabel Penelitian}

Variabel Independen terdiri dari: (1) jenis industri (2) ukuran perusahaan, (3) tingkat keuntungan perusahaan; (4) tingkat pengungkit dan (5) jenis auditor. Variabel dependen yaitu informasn laporan keuangan (berdasarkan kriteri penilaian) pada laman seratus perusahaan teratas yang terdaftar di Bursa Efek Indonesia berdasarkan indeks KOMPAS100 (Y).

\section{Objek Penelitian}

Objek penelitian adalah laman 100 perusahaan teratas yang terdaftar di Bursa Efek Indonesia. Laman perusahaan ini dilihat untuk mengetahui luasnya pengungkapan laporan keuangan berbasis internet. Sebagai indikator peringkat 100 perusahaan teratas, penelitian ini menggunakan indeks KOMPAS100. Berdasarkan pejelasan pada laman BEI yang diakses hari Kamis tanggal 10 April 2009, Indeks KOMPAS100 merupakan Indeks Harga Saham yang dibuat atas hasil kerjasama Bursa Efek Indonesia dengan harian KOMPAS. Indeks KOMPAS100 terdiri dari 100 perusahaan yang telah memenuhi persyaratan untuk masuk dalam indeks KOMPAS100.

Adapun persyaratan yang dimaksud yaitu: (1) Telah tercatat di BEI minimal 3 bulan; (2) saham tersebut termasuk dalam perhitungan IHSG (Indeks Harga Saham Gabungan); (3) berdasarkan pertimbangan faktor fundamental perusahaan dan pola perdagangan di bursa, BEI dapat menetapkan untuk mengeluarkan saham tersebut dalam proses perhitungan indeks harga 100 saham; (4) masuk dalam 150 saham dengan nilai transaksi dan frekuensi transaksi serta kapitalisasi pasar terbesar di Pasar Reguler, selama 12 bulan terakhir; (5) dari sebanyak 150 perusahaan tersebut, kemudian diperkecil jumlahnya menjadi 60 saham dengan pertimbangan nilai transaksi terbesar; (6) dari sebanyak 90 saham tersisa, kemudian dipilih sebanyak 40 saham dengan mempertimbangkan kinerja: hari transaksi dan frekwensi transaksi serta nilai kapitalisasi pasar di pasar reguler, dengan proses sebagai berikut: (a) dari 90 sisanya, akan dipilih 75 saham berdasarkan transaksi di pasar regular, (b) dari 75 saham tersebut akan dipilih 60 saham berdasarkan frekuensi transaksi di pasar regular, (c) dari 60 saham tersebut akan dipilih 40 saham berdasarkan kapitalisasi pasar; (7) daftar 100 saham diperoleh dengan menambah daftar saham dari hasil perhitungan butir (5) ditambah dengan daftar saham hasil perhitungan butir (6). 


\section{Model Empiris}

Model empiris disusun berdasarkan seluruh variabel independen dalam penelitian ini. Khusus untuk variabel independen jenis industri dan audit oleh empat KAP (Kantor Akuntan Publik) terbesar di Indonesia, maka akan menggunakan variabel kategori (dummy). Untuk jenis indstri, akan diberikan peringkat penilaian. Sedangkan perusahaan yang diaudit oleh 4 KAP terbesar di Indonesia akan mendapat poin 1 dan untuk perusahaan yang tidak diaudit oleh 4 KAP terbesar di Indonesia akan mendapat poin 0. Dengan demikian, dapat dibentuk suatu model empiris sebagai berikut:

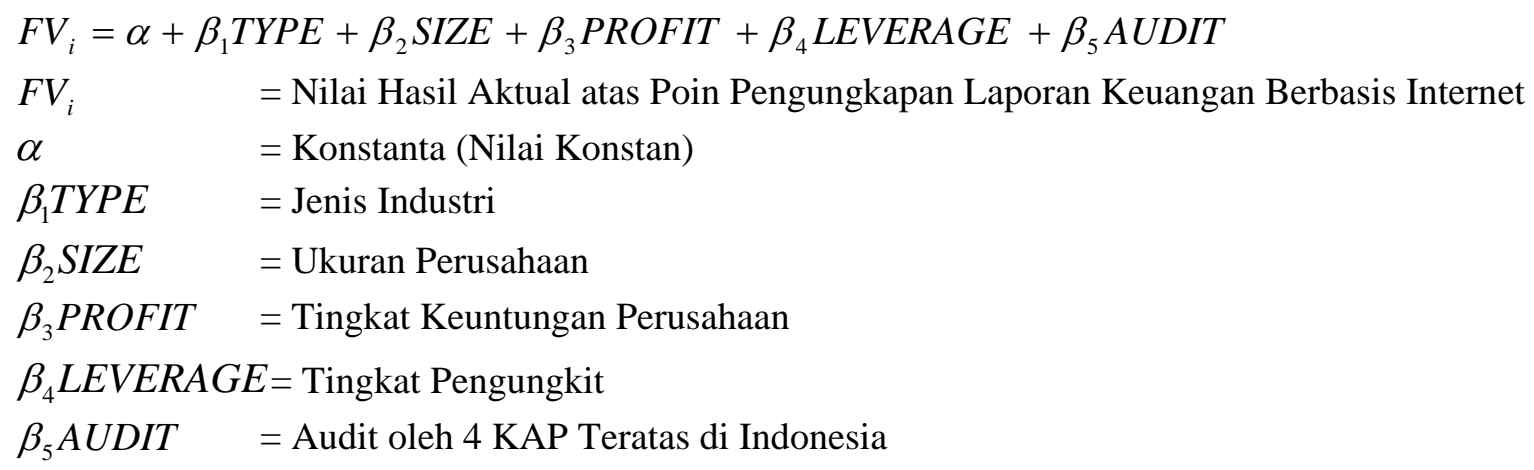

Model empiris ini berdasarkan model empiris yang dibentuk pada penilitian Abdelsalam et al (2007). Namun pada Abdelsalam et al (2007) yang menjadi variabelnya adalah MAJORHOLDING (persentase pemegang saham utama), DIRECTORHOLDING (persentase saham direktur), INDEPENDENCE (proporsi direktur independen), DUALROLE (bernilai 1 jika direktur juga bertindak sebagai komisaris, 0 jika tidak), ANALISTS (jumlah analis perusahaan), MFG_IND (pengelompokan industri manufaktur dan nonmanufaktur), ROA (tingkat pengembalian harta), TOT_ASSETS (total aset), dan MKTCAP_BV (nilai pasar).

Adapun variabel-variabel independen dalam penelitian ini yaitu: (1) Jenis Industri (TYPE), dalam penelitian ini, jenis industri akan di bagi sesuai industri-industri yang terdapat dalam sampel penelitian; (2) Besar Perusahaan (SIZE), besar perusahaan dilihat dari total aset yang dimiliki perusahaan pada tahun 2008. Tahun 2008 digunakan sebagai batas waktu karena dianggap mewakili informasi pada tahun 2009. Adapun landasan penggunaan total aset sebagai tolak ukur besar perusahaan adalah pada penelitian Asbough et al (1999) dan Xiao et al (2003); (3) Tingkat Keuntungan (PROFIT), pada penelitian Pervan (2004) menggunakan ROA untuk menghitung tingkat keuntungan. Asbough et al (1999) juga menggunakan ROA sebagai salah satu variabel penelitiannya. Penggunaan ROA juga ditemukan pada penelitian Sriram dan Laksamana (2006) serta dalam penelitian Abdelsalam (2007). Melihat penggunaan ROA sebagai dasar perhitungan tingkat keuntungan telah digunakan pada beberapa penelitian sebelumnya, maka penelitian ini juga akan menggunakan ROA dalam perhitungan tingkat kentungan. (4) Tingkat Pengungkit (LEVERAGE), penggunaan tingkat pengungkit dalam penelitian ini sejalan dengan penelitian Xiao et al (2004) yang memasukan tingkat pengungkit sebagai salah satu variabel penelitiannya. Untuk membandingkan tingkat penggunaan utang untuk modal, maka akun utang yang dipakai adalah akun yang terdapat pada utang jangka panjang. Karena akun utang dalam tiap perusahaan berbeda-beda, maka tidak ada standar baku mengenai akun apa saja yang akan masuk dalam perhitungan, selama akun tersebut termasuk dalam utang jangka panjang atau didefinisikan sebagai utang jangka panjang. (5) Kelompok Auditor (AUDITOR), kelompok auditor yang dimaksud dalam penelitian ini adalah auditor yang termasuk dalam 4 KAP terbesar di Indonesia dan auditor selain 4 KAP terbesar di Indonesia. Kemudian kelompok auditor ini akan diberi angka satu untuk yang termasuk dalam 4 auditor teratas di Indonesia dan 0 untuk yang bukan. 


\section{HASIL DAN PEMBAHASAN}

\section{Hasil Kriteria Penilaian}

Berdasarkan total 29 poin pada kriteria penilaian, ke 69 sampel penelitian memenuhi 59,17\% dari total poin. Adapun persentase Informasi Laporan Keuangan, terpenuhi sebesar 49,28\%. Untuk Informasi Kinerja Managemen hanya mencapai $12,46 \%$. Selanjutnya, persentase yang terpenuhi untuk Informasi Saham hanya mencapai 19,57\%. Informasi Penjualan dan Pendapatan terpenuhi sebesar 29,35\%. Kemudian, persentase yang lebih besar dicapai untuk Informasi Pegawai dan Direktur yaitu sebesar 39,86\%. Terakhir, untuk Informasi umum persentase yang terpenuhi adalah sebesar 48,24\%.

\section{Hasil Uji Statistik Deskriptif}

Berdasarkan hasil pengumpulan informasi terhadap 69 perusahaan maka didapatkan data penelitian dalam bentuk deskriptif. Seluruh sampel penelitian dapat memenuhi data untuk variabel dependen (presentase IFR) dan dapat memenuhi data untuk variabel independen. Namun terdapat satu perusahaan yang tidak dapat didefinisikan berdasarkan bantuan Investor Daily per 12 Juni 2009 yaitu Titan Kimia Nusantara Tbk. Sehingga pada hasil data penelitian, Titan Kimia Nusantara Tbk tidak diberikan angka 1 pada salah satu industri melainkan angka 0. Dengan demikian, perhitungan SPSS dapat menghitung total nilai $\mathrm{N}$ sebesar 69 sampel penelitian.

Tabel 1 Jenis Industri

\begin{tabular}{llr}
\hline No. & Jenis Industri & Jumlah \\
\hline 1. & Pertanian & 5 \\
2. & Pertambangan & 9 \\
3. & Industri Dasar dan Kimia & 10 \\
4. & Aneka Industri & 4 \\
5. & Industri Barang Konsumsi & 6 \\
6. & Properti dan Real Estate & 14 \\
7. & Infrastruktur, Utilitas, dan Transportasi & 10 \\
8. & Perdagangan, Jasa, dan Investasi & 10 \\
9. & Tidak Terdefinisi & 1 \\
\hline Total & & 69 \\
\hline
\end{tabular}

Nilai minimum variabel SIZE dari 69 sampel penelitian sebesar 2,591 (log dari Rp 180.549.748.739) dengan nama perusahaan Yanaprima Hastrapersada Tbk. Sedangkan untuk variabel PROFIT, Mobile-8 Telecom Tbk menempati posisi nilai minimum dengan total ROA sebesar -0,246. Nilai minimum untuk variabel LEVERAGE dimiliki oleh Pakuwon Jati Tbk dengan nilai 0.001.

Tabel 2 Nilai Minimum

\begin{tabular}{llll}
\hline No & Variabel & $\mathrm{N}$ & Minimum \\
\hline 1. & SIZE & 69 & 2,591 \\
2. & PROFIT & 69 & $-0,246$ \\
3. & LEVERAGE & 69 & 0,001 \\
\hline
\end{tabular}

Nilai Maksimum untuk variabel SIZE jatuh pada Telekomunikasi Indonesia Tbk dengan nilai 3,214 (log dari Rp 91.256.250.000.000). Untuk variabel PROFIT, nilai ROA maksimumnya adalah 0.606 yang diperoleh Astra Agro Lestari Tbk. Kemudian, nilai maksimum untuk variabel LEVERAGE adalah 0.625 dengan nama perusahaan Mobile-8 Telecom Tbk. 
Tabel 3 Nilai Maksimum

\begin{tabular}{llll}
\hline No & Variabel & $\mathrm{N}$ & Maksimum \\
\hline 1. & SIZE & 69 & 3,214 \\
2. & PROFIT & 69 & 0,606 \\
3. & LEVERAGE & 69 & 0,625 \\
\hline
\end{tabular}

Mean untuk variabel SIZE adalah 2,911 (log dari Rp 95.690.838.460.073) Mean untuk variabel PROFIT adalah 0,094. Sedangkan Mean untuk variabel LEVERAGE sebesar 0,219.

Tabel 4 Nilai Mean

\begin{tabular}{llll}
\hline No & Variabel & $\mathrm{N}$ & Mean \\
\hline 1. & SIZE & 69 & 2,911 \\
2. & PROFIT & 69 & 0,094 \\
3. & LEVERAGE & 69 & 0,219 \\
\hline
\end{tabular}

\section{Hasil Uji Model Empiris dan Akurasi (Regresi)}

Berdasarkan hasil penelitian dan hasil perhitungan statisik dengan menggunakan uji regresi $F V_{i}=\alpha+\beta_{1} T Y P E+\beta_{2} S I Z E+\beta_{3}$ PROFIT $+\beta_{4} L E V E R A G E+\beta_{5} A U D I T$ (model empiris penelitian), maka di dapatkan suatu nilai sebesar 0,397. Berdasarkan hasil analisis Anova, nilai $\mathrm{F}=$ 3,413 dengan tingkat signifikan 0,001.

Berdasarkan uji regresi yang didapat, muncul nilai aktual model empiris sebesar 0,397. Nilai ini berarti variabel dependen dipengaruhi oleh variabel independen sebesar 39,70\%, sedangkan $60,30 \%$ variabel dependen dipengaruhi oleh faktor lain. Angka persentase ini sangat wajar, karena tentunya luas pengungkapan informasi laporan keuangan berbasis internet pada sampel penelitian juga sangat ditentukan oleh banyak faktor-faktor lain. Seperti kepemilikan saham, pembagian deviden, susunan managemen, dan lain sebagainya.

\section{Hasil Koefisien Regresi dengan Uji t}

Dalam penelitian ini, uji hipotesis menggunakan bantuan dari uji t untuk melihat apakah diterima. Data tabel hasil uji t ini dapat dilihat pada halaman lampiran dengan nama Tabel IV.7. Hasil Uji t. Berdasarkan hasil penelitian dan hasil perhitungan statistik dengan bantuan uji t, maka didapatkan keputusan atas hipotesis sebagai berikut:

$H A_{1}$ : Jenis industri berpengaruh terhadapat informasi laporan keuangan yang diungkapkan pada laman perusahaan. Hipotesis alternatif belum dapat diterima. Karena pada tabel uji t dengan bantuan SPSS 17, variabel TYPE yang terdiri dari 8 jenis industri (yang dipakai hanya 7, Aneka Industri diabaikan), tidak menunjukkan kondisi dapat diterimanya hipotesis alternatif. Karena nilai SIG dari ketujuh industri tersebut adalah Pertanian $(0,703)$, Pertambangan $(0,204)$, Industri Dasar dan Kimia $(0,052)$, Industri Barang Konsumsi $(0,944)$, Properti dan Real Estate $(0,193)$, Infrastruktur, Utilitas, dan Transportasi $(0,413)$, Perdagangan, Jasa, dan Transportasi $(0,127)$. Secara umum, nilai SIG berada di atas 0,1 yang artinya tidak ada pengaruh. 
$\mathrm{HA}_{2}$ : Ukuran perusahaan berpengaruh terhadap informasi laporan keuangan yang diungkapkan pada laman perusahaan. Hipotesis diterima dengan tingkat signifikan sebesar $1 \%$. Karena pada tabel uji t dengan bantuan SPSS 17, variabel SIZE memiliki nilai SIG sebesar 0,000.

$H A_{3}$ : Tingkat keuntungan perusahaan berpengaruh terhadap informasi laporan keuangan yang diungkapkan pada laman perusahaan. Hipotesis diterima dengan tingkat signifikan sebesar 5 $\%$. Karena pada tabel uji t dengan bantuan SPSS 17, variabel PROFIT memiliki nilai SIG sebesar 0,031 .

$\mathrm{HA}_{4}$ : Tingkat pengungkit berpengaruh terhadap informasi laporan keuangan yang diungkapkan pada laman perusahaan. Hipotesis belum dapat diterima. Karena pada tabel uji t dengan bantuan SPSS 17, variabel LEVERAGE memiliki nilai SIG sebesar 0,552.

$H A_{5}$ : Kelompok auditor berpengaruh terhadap informasi laporan keuangan yang diungkapkan pada laman perusahaan. Hipotesis belum dapat diterima. Karena pada tabel uji t dengan bantuan SPSS 17, variabel AUDITOR memiliki nilai SIG sebesar 0,413.

\section{Kriteria Penilaian}

Berdasarkan penelusuran laman dari 69 sampel penelitian, kemudian informasi laporan keuangan yang terdapat di dalamnya dibandingkan dengan kriteria penilaian. Maka didapatkan hasil bahwa total poin yang dapat dipenuhi dari kriteria penilaian adalah sebesar 59,17\%. Presentase ini menunjukan bahwa sebagain besar sampel perusahaan telah memenuhi kriteria penilaian. Jika dihitung secara kolektif, maka total nilai yang akan muncul ketika seluruh kriteria penilaian terpenuhi oleh 69 sampel penelitian adalah 2001 poin (69 sampel x 29 poin kriteria penilaian). Dengan demikan secara kolektif, total presentase sebesar 59,17\% dapat juga diartikan bahwa total poin yang terpenuhi dari kriteria penilaian adalah sebesar 17 poin dan 12 poin lainnya tidak terpenuhi. Angka persentase sejumlah 59,17\% untuk total poin kriteria penilaian dapat dikatakan cukup baik secara umum. Karena di Indonesia belum ada aturan standar yang mengatur pengungkapan informasi laporan keuangan berbasis internet, namun dari sampel penelitian sudah sebagian besar memenuhi kriteria penilaian yang mewakili informasi penting yang dibutuhkan oleh pengguna informasi.

Total persentase di atas perlu ditelaah lebih lanjut. Informasi pertama yang akan dibahas adalah Informasi Laporan keuangan. Secara umum, total persentase untuk Informasi Laporan Keuangan adalah 49,28\%. Untuk informasi ini, sampel penelitian dinilai cukup karena mendekati $50 \%$. Bukti pengamatan menghasilkan bahwa sebagian besar sampel sudah menyediakan informasi laporan keuangan untuk tahun 2008, 2007, dan lebih dari setengah sampel (47 perusahaan) menyediakan laporan keuangan tahun 2006. Namun tidak semua laporan keuangan tersebut telah ditandatangani oleh direktur dan auditor. Kondisi ini mengakibatkan kurang dapat diandalkannya informasi dalam laporan keuangan yang tidak bertandatangan. Karena isinya tidak dapat dipertanggungjawabkan oleh pihak tertentu.

Berlanjut ke informasi selanjutnya yaitu Informasi Kinerja Managemen. Hasil yang tidak memuaskan didapat dari informasi ini, karena total persentase hanya sebesar 12,46\%. Rata-rata, di bawah 20 perusahaan yang mengungkapkan informasi ini. Kondisi ini kurang baik, karena para pengguna informasi tidak dapat menilai hasil kerja managemen. Jika pengguna laporan keuangan tidak bisa mendapatkan informasi kinerja managemen dengan mudah, maka keputusan pengguna informasi juga tidak akan maksimal. Kenyataan ini dapat memunculkan suatu kondisi informasi yang asimetri, di mana pihak perusahaan mungkin menyaring informasi yang tidak diinginkan untuk dipublikasikan kepada masyarakat umum. Tampak dari hasil penelitian, bahwa perusahaan belum sepenuhnya terbuka atas informasi internalnya. Atau juga dapat diartikan bahwa perusahaan tidak terus memutakhirkan 
informasi pada laman perusahaan. Karena pada beberapa perusahaan, terdapat suatu bagian yang menjelaskan kinerja managemen beserta kelebihan dan kekurangan dari kinerja managemen. Namun informasi tersebut sudah lewat dua atau tiga tahun ke belakang. Melihat keadaan ini, perusahaanperusahaan yang menjadi sampel penelitian kurang memberikan perhatian atas perlunya informasiinformasi yang selalu diperbaharui. Tidak hanya terbatas pada laporan keuangan beserta ringkasan keuangannya, namun informasi kinerja managemen juga harus terus diperbaharui. Dengan demikian, para investor, stakeholder, maupun masyarakat umum akan lebih tertarik dengan kondisi perusahaan. Serta mungkin saja terjadi pada pihak yang berkepentingan lebih termotivasi untuk berhubungan dengan perusahaan.

Keadaan yang serupa juga dijumpai pada Infromasi Saham. Perusahaan yang menjadi sampel penelitian kurang informatif dalam hal saham. Sangat sedikit perusahaan yang mengungkapakan informasi yang dibutuhkan dalam kriteria penilaian. Terbukti dari hasil penelitian untuk Informasi Saham hanya mencapai 19,57\%. Tidak lebih dari 20 perusahaan yang mengungkapkan informasi ini. Hal ini mengindikasikan kurang pedulinya perusahaan terhadap informasi perkembangan saham. Kondisi ini juga mempersulit para pengguna informasi dalam mengolah informasi saham. Dengan demikian, informasi yang terdapat dalam laman perusahaan kurang dapat mendukung investor dalam memantau pergerakan saham perusahaan. Selain itu, kurangnya informasi ini juga dapat memunculkan kemungkinan berkurangnya motivasi calon investor yang ingin berinvestasi pada perusahaan.

Persentase kriteria penilaian sedikit meningkat pada Informasi Penjualan dan Pendapatan. Namun persentase ini juga dinilai masih belum memuaskan yaitu sebesar 29,35\%. Kurangnya informasi ini menandakan perusahaan belum dapat menggunakan lamannya di internet sebagai media signalling perusahaan. Sebenarnya informasi penjualan dan pendapatan dapat dijadikan sebagai pertanda untuk para stakeholder maupun masyarakat umum bahwa perusahaan telah melakukan kinerja yang baik dan mendapat keuntungan yang memuaskan. Dengan terpenuhinya informasi tentang penjualan, akan dapat memicu para stakeholder untuk tetap menjaga kerjasama dengan perusahaan. Sedangkan informasi pendapatan, mungkin saja dapat menarik investor untuk berinvestasi pada perusahaan karena dinilai menguntungkan. Dengan pertumbuhan pendapatan yang sehat tentu banyak investor yang tertarik pada keuntungan yang juga akan mereka terima jika berinvestasi pada perusahaan.

Informasi Pegawai dan Direktur memiliki nilai persentase sebesar 38,86\%. Informasi tentang pegawai dan direktur ini dianggap penting karena dua hal. Pertama, informasi tentang karyawan dapat memberikan gambaran kepada pengguna informasi laporan keuangan berbasis internet tentang seberapa besar ukuran perusahaan dan seberapa efisien kinerja perusahaan. Dengan adanya informasi seperti jumlah karyawan dan sistem kerja karyawan, para pengguna informasi dari laman perusahaan dapat membandingkan jenis usaha perusahaan, ruang lingkup usaha, dan hasil yang didapat dengan hubungannya tingkat efisiensi penggunaan karyawan. Sedangkan informasi direktur dipercaya dapat memberikan nilai tambah ketika stakeholder ataupun investor ingin memutuskan sesuatu terhadap perusahaan. Direktur dengan tingkat pendidikan yang berkualitas serta pengalaman yang sudah teruji akan semakin menumbuhkan rasa kepercayaan pihak-pihak yang berkepentingan terhadap perusahaan dan langkah-langkah yang diputuskan oleh para dewan direksi.

Informasi Umum merupakan informasi kedua terbesar yang terpenuhi dengan nilai persentase sebesar 48,24\%. Hampir seluruh sampel mengungkapkan sejarah dan ruang lingkup usaha. Informasi ini bermanfaat bagi pengguna informasi untuk mengetahui termasuk usaha dan sejarah perusahaan. Salah satu poin yang juga terpenuhi cukup tinggi adalah kebijakan sosial. Kebijakan sosial ini, bisa saja mengurangi pajak penghasilan perusahaan jika terkait dengan bencana nasional ataupun persyaratan lain yang diperbolehkan oleh Direktorat Jenderal Pajak. 


\section{Pengaruh Jenis Industri terhadap Informasi Laporan Keuangan Berbasis Internet}

Beranjak ke pembahasan selanjutnya yaitu mengenai hasil uji hipotesis. Hipotesis pertama yang memprediksikan adanya hubungan antara jenis industri dengan luas pengungkapan informasi laporan keuangan berbasis internet untuk penelitian kali ini belum dapat diterima. Kondisi ini sejalan dengan penelitian Marston (2003) yang tidak dapat menolak hipotesis null atas hubungan jenis industri dengan keluasan pengungkapan informasi laporan keuangan berbasis internet.

Hal ini dapat terjadi dalam penelitian kali ini karena pemilihan sampel dilakukan berdasarkan indeks KOMPAS100 yang terdiri dari beragam industri dengan komposisi yang kurang seimbang. Jika sampel penelitian diperluas sehingga mendapat keseimbangan persebaran jenis industri, mungkin saja hipotesis alternatif dapat diterima. Penerimaan hipotesis alternatif atas jenis industri akan semakin kuat jika industri dikelompokan berdasarkan dua kelompok besar seperti pada penelitian Abdelsalam et al (2007) yang mengelompokan industri manufaktur dengan non-manufaktur, serta penelitian Xiao et al (2004) yang mengelompokan industri teknologi informasi dengan yang non teknologi informasi. Dengan pengelompokan yang semakin mengerucut itu, perubahan pada variabel jenis industri mungkin akan diikuti sejalan dengan perubahan variabel dependen yaitu informasi laporan keuangan. Karena tidak menutup kemungkinan perusahaan dalam industri yang sama saling berkompetisi dalam hal publikasi perusahaan pada berbagai pihak, dan internet menjadi salah satu media yang dipilih dalam berkompetisi dengan para pesaingnya dari industri sejenis.

\section{Pengaruh Ukuran Perusahaan terhadap Informasi Laporan Keuangan Berbasis Internet}

Hipotesis kedua dalam penelitian ini dapat diterima dengan tingkat signifikan 1\%. Dari hasil penelitian pada 69 perusahaan di Indonesia, terbukti bahwa ukuran perusahaan berpengaruh terhadap luasnya pengungkapan informasi laporan keuangan berbasis internet. Berdasarkan pengamatan secara langsung ketika pengumpulan data, tebukti perusahaan dengan ukuran lebih besar menampilkan informasi secara lebih baik dan lebih detail. Kondisi ini terjadi kemungkinan dikarenakan perusahaan besar memiliki banyak hubungan dengan berbagai pihak. Sehingga internet, menjadi salah satu media yang baik untuk berkomunikasi dengan pihak-pihak terkait termasuk masyarakat. Perusahaanperusahan besar cenderung mengungkapkan informasi lebih banyak untuk mencapai tujuan tertentu.

Hal ini sejalan dengan signalling theory yang menyatakan bahwa perusahaan akan memberikan tanda kepada stakeholder dan masyarakat bahwa perusahaan dalam kondisi tertentu sehingga tanda yang diberikan perusahaan ini dapat mengarahkan keputusan stakeholder atau masyarakat untuk mendukung keuntungan maupun tujuan perusahaan. Faktor yang tidak kalah pentingnya dari motivasi perusahaan besar untuk mengungkapkan informasi laporan keuangan lebih luas terkait dengan agency theory dan agency cost. Dengan pengungkapan yang lebih luas, kinerja managemen juga dapat terpantau masyarakat umum yang akhirnya dapat mengurangi biaya pengawasan yang harus dikeluarkan perusahaan. Terakhir terkait dengan political cost, ada kemungkinan perusahaan berusaha mengurangi biaya tersebut dengan keluasan informasi laporan keuangan. Hasil penelitian ini sejalan dengan penelitian Sriram dan Laksmana (2006) yang juga membuktikan adanya pengaruh antara ukuran perusahaan dengan luas pengungkapan informasi laporan keuangan, mereka menyatakan bahwa perusahaan besar cendrung memberikan informasi secara lebih luas agar mendapat keuntungan dari mengurangi ketidakpastian investor. Dengan informasi yang lebih jelas, investor juga akan lebih yakin untuk berinvestasi pada perusahaan. Selain Sriram dan Laksmana (2006), penelitian Marston (2003) juga membuktikan adanya pengaruh ukuran perusahaan dengan tingkat keluasan pengungkapan informasi laporan keuangan berbasis internet. 


\section{Pengaruh Tingkat Keuntungan Perusahaan terhadap Informasi Laporan Keuangan Berbasis Internet}

Pada penelitian terhadap 69 perusahan di Indonesia, tingkat keuntungan terbukti berpengaruh terhadap keluasan informasi laporan keuangan berbasis internet. Pernyataan ini bersumber dari hasil uji t yang menerima hipotesis alternatif yang ketiga dengan tingkat signifikan $5 \%$. Sebagaimana telah dijelaskan pada pembentukan hipotesis di bab 2, bahwa perusahaan dengan tingkat keuntungan yang semakin tinggi akan mengungkapkan informasi yang lebih banyak pula. Karena banyak faktor-faktor yang perlu diumumkan berkaitan dengan tingkat keuntungan, dan tingkat keuntungan merupakan salah satu hal yang paling menarik untuk dilihat oleh stakeholder maupun masyarakat umum. Maka dari itu, tingkat keuntungan yang baik dapat menjadi andalan perusahaan untuk mencerminkan bahwa perusahaan berada dalam kondisi yang aktif dan sehat. Sehingga memunculkan opini yang positif dari masyarakat dan stakeholder.

Hasil penelitian yang mampu membuktikan pengaruh tingkat keuntungan dengan keluasan pengungkapan informasi laporan keuangan berbasis internet adalah Poon et al (2003) yang menyatakan perusahaan yang termasuk dalam 100 saham terbesar di Hong Kong, dengan keuntungan lebih besar memiliki kesempatan atau motivasi yang lebih tinggi pula dalam mengimplementasikan pengungkapan informasi laporan keuangan berbasis internet. Walaupun beberapa penelitian lain tidak sejalan dengan hasil ini misalnya, Marston (2003) dan Abdelsalam et al (2007) yang belum dapat membuktikan pengaruh tingkat keuntungan dengan pengungkapan informasi laporan keuangan berbasis internet. Kenyataan ini menandakan bahwa keluasan informasi pada laman perusahaan di tiap negara dipengaruhi oleh faktor yang berbeda seperti di Jepang dan Inggris, tingkat keuntungan bukan faktor yang turut menentukan. Sedangkan di Indonesia dan di Hong Kong, tingkat keuntungan merupakan salah satu faktor yang menentukan. Hal ini terjadi karena perbedaan kondisi ekonomi dan perbedaan model kompetisi usaha pada tiap negara.

\section{Pengaruh Tingkat Pengungkit terhadap Informasi Laporan Keuangan Berbasis Internet}

Hipotesis keempat yang berusaha menjelaskan pengaruh antara tingkat pengungkit dengan keluasan informasi laporan keuangan berbasis internet pada penelitian kali ini belum dapat diterima. Hasil ini dapat diartikan bahwa tingkat pengungkit bukanlah suatu faktor yang menentukan perilaku perusahaan dan keputusan dari stakeholder termasuk para investor terhadap perusahaan. Namun tidak menutup kemungkinan, jika tingkat pengungkit diujicobakan lagi pada periode mendatang di mana kondisi ekonomi sedang berfluktuasi tinggi dan berubah-ubah dengan cepat, tingkat pengungkit dapat menentukan informasi apa saja yang diungkapkan lewat laman suatu perusahaan. Salah satu penyebab tidak berpengaruhnya tingkat pengungkit terhadap pengungkapan informasi laporan keuangan pada sampel penelitian di Indonesia, mungkin saja karena pengaruh tetap berthannya ekonomi Indonesia pada saat krisis keuangan menimpa dunia. Indonesia dianggap mampu bertahan, sehingga penggunaan utang sebagai pembiayaan usaha tidak dinilai mengkhawatirkan. Pelaku usaha yakin perputaran usaha mereka akan berjalan normal sehingga likuiditas maupun solvabilitas usaha dapat terjamin.

Faktor lain yang mungkin menyebabkan kurang terlihatnya pengaruh tingkat pengungkit terhadap pengungkapan informasi laporan keuangan berbasis internet adalah kriteria penilaian. Jika kriteria penilaian di modifikasi pada kesempatan penelitian selanjutnya yang lebih mengarah pada tingkat pengungkit, tidak menutup kemungkinan adanya pengaruh tingkat pengungkit terhadap informasi yang disampaikan perusahaan di Indonesia pada lamannya.

\section{Pengaruh Jenis Auditor terhadap Informasi Laporan Keuangan Berbasis Internet}

Beranjak ke hasil penelitian selanjutnya, uji statistik menyatakan bahwa tidak ada pengaruh antara kelompok auditor dengan luas pengungkapakn informasi laporan keuangan berbasis internet di Indonesia. Hasil ini tidak sejalan dengan penelitian Xiao et al (2004) yang menyatakan adanya 
pengaruh antara auditor dengan pengungkapan informasi laporan keuangan berbasis internet di China. Namun pada penelitian Xiao et al (2004) variabel auditor di gabung dengan variabel lain menjadi satu, kemudian dari kesatuan variabel ini diujicobakan terhadap variabel dependen sehingga didapat suatu pengaruh kolektif terhadap variabel dependen. Selain itu, kemungkinan adanya pengaruh auditor terhadap variabel dependen pada penelitian Xiao et al (2004) karena auditor yang tergabung dalam big-5 mempunyai tanggung jawab atas informasi laporan keuangan yang disampaikan kliennya di internet. Karena di China ada peraturan yang mengatur tentang pengungkapan informasi laporan keuangan berbasis internet. Sedangkan di Indonesia, belum ada pihak regulator yang mengeluarkan aturan penggunaan internet sebagai media pengungkapan informasi laporan keuangan. Sehingga belum ada kewajiban untuk para auditor khusunya yang tergabung dalam big-4 untuk menjamin keandalan informasi laporan keuangan yang disampaikan kliennya pada laman perusahaan lewat internet. Namun tidak menutup kemungkinan, ketika pengungkapan informasi laporan keuangan sudah menjadi suatu tren di Indonesia peranan auditor yang tergabung dalam big-4 dapat menjadi salah satu faktor penentu luasnya pengungkapan informasi laporan keuangan berbasis internet.

\section{PENUTUP}

Terdapat 69 perusahaan pada kumpulan KOMPAS100 yang memiliki laman perusahaan, diluar industri keuangan. Tiap perusahaan mempunyai format sendiri dalam lamannya. Sehingga informasi laporan keuangan yang disampaikan juga berbeda-beda bagi masing-masing perusahaan. Perbedaan bentuk penyampaian informasi laporan keuangan berbasis internet terjadi karena adanya perbedaan tujuan tiap perusahaan dalam memanfaatkan laman perusahaannya di internet. Selain itu, tidak adanya standar aturan yang harus dipenuhi perusahaan di Indonesia dalam mengungkapkan informasi laporan keuangan berbasis internet. Dalam hal pemenuhan poin kriteria penilaian, sampel penelitian dapat dikatakan cukup memenuhi. Karena total poin yang terpenuhi adalah sebesar 59,17\% yang artinya lebih dari setengah kriteria penilaian terpenuhi. Melihat tidak adanya standar yang harus diikuti perusahaan dalam hal pengungkapan informasi laporan keuangan berbasis internet. Maka angka persentase di atas dinilai cukup memuaskan. Namun tidak semua pemenuhan kriteria penilaian ini terdistribusi dengan baik, hanya Informasi Laporan Keuangan dan Informasi Umum saja yang hampir mencapai 50\%. Dari lima analisis hipotesis yang ada dalam penelitian ini, disimpulkan bahwa untuk penelitian kali ini faktor-faktor yang mempengaruhi luasnya pengungkapan informasi laporan keuangan berbasis internet adalah ukuran perusahaan dan tingkat keuntungan perusahaan. Sedangkan untuk jenis industri, tingkat pengungkit, dan jenis auditor, untuk saat ini belum dapat dijelaskan pengaruhnya. Dengan demikian faktor-faktor yang bernilai sensitif terhadap pengungkapan informasil laporan kauangan berbasis internet adalah ukuran perusahaan dan tingkak keuntungan perusahaan

\section{Keterbatasan Penelitian}

Dalam suatu penelitian tentunya hasil penelitian yang disajikan tidak terlepas dari keterbatasanketerbatasan yang menyebabkan hasil suatu penelitian tidak sempurna. Begitupula dengan penelitian pada penelitian ini yang meneliti tentang keluasan pengungkapan informasi laporan keuangan berbasis internet pada perusahaan yang termasuk dalam indeks KOMPAS100. Keterbatasan pertama adalah sangat minimnya penelitian mengenai pengungkapan informasi laporan keuangan (IFR) di Indonesia. Sehingga sulit untuk mencari bahan literatur yang dapat mendukung penelitian pada penelitian ini. Kedua adalah permasalahan penyusunan kriteria penilaian. Kriteria penilaian yang disusun sebagai instrumen penelitian dalam penelitian ini merujuk pada penelitian serupa di luar negeri. Sehingga kriteria penilaian yang digunakan mungkin tidak dapat mewakili informasi laporan keuangan yang harus diungkapkan pada laman perusahaan di Indonesia. Keterbatasan selanjutnya yang masih terkait kriteria penilaian adalah tidak adanya aturan di Indonesia yang mengatur perusahaan-perusahaan yang sudah terdaftar di Bursa Efek Indonesia dalam hal pengungkapan informasi laporan keuangan berbasis internet. 


\section{DAFTAR PUSTAKA}

Abdelsalam, O.H., \& Street, D.L. (2007). Corporate governance and the timeliness of corporate internet reporting by U.K. listed companies. Journal of International Accounting, Auditing and Taxation, 16, 111-130.

Allam, A. \& Lymer, A. (2003). Development in Internet Financial Reporting: Review and Analysis Across Five Developed Countries. The International Journal of Digital Accounting Research, 3(6), 165-199.

Asbough, H., Johnstone, K. M., \& Warfield, T. D. (1999). Corporate reporting on the internet. Accounting Horizons, 13(13).

Budisusetyo, S. \& Almilia, L. S. (2008). The practice of financial disclosure on corporate website: Case study in Indonesia. Paper dipresentasikan pada International Conference on Business \& Management, University Brunei Darussalam.

Lymer, A. (1999). The Internet and the future of corporate reporting in Europe. European Accounting Review, 2(2), 289-301.

Marston, C. \& Polei, A. (2004). Corporate reporting on the internet by German companies. International Journal of Accounting Information System, 5, 285-311.

Pervan, I. (2005). Financial reporting on the internet and the practice of Croatian join stock companies quotes on the stock exchanges. Finansial Theory and Practice 29 (2), 159-174.

Poon, P. \& Li, D. (2003). Internet financial reporting. Information System Control Journal, 1.

Sriram, R. S. \& Laksmana, I. (2006). Corporate website reports some evidence on relevance and usefulness. Information Resources Management Journal, 19(3).

Xiao, J.Z., Yang, H. \& Chow, C.W. (2004). The determinants and characteristics of voluntary Internet-based disclosures by listed Chinese companies. Journal of Accounting and Public Policy, 23, 191-225. 